\title{
Originals
}

\section{Evidence that the reduced number of natural killer cells in Type 1 (insulin-dependent) diabetes may be genetically determined}

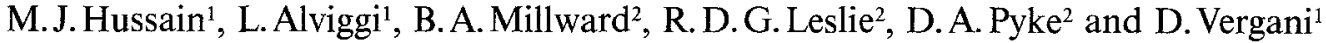 \\ Departments of 'Immunology and 'Diabetes, King's College School of Medicine and Dentistry, London, UK
}

\begin{abstract}
Summary. Viruses may cause Type 1 (insulin-dependent) diabetes. We wondered whether the number and function of natural killer cells, which are important in anti-viral defense, are disturbed in diabetic patients. We studied 16 recently diagnosed Type 1 diabetic patients, 18 Type 1 diabetic patients diagnosed more than 15 years previously, 18 Type 2 (non-insulin-dependent) diabetic patients and 23 control subjects. We determined the number of natural killer cells (expressed as $\log _{10} \%$ ) using anti-Leu 11 monoclonal antibody and the function (in $\log _{10}$ lytic units) concurrently using a ${ }^{51} \mathrm{Cr}$ release assay with $\mathrm{K} 562$ as target cells. We found that the number of natural killer cells was reduced in Type 1 diabetes (1.01士 $0.04)$ as compared with Type 2 diabetic patients $(1.16 \pm 0.04$, $p=0.004)$ and normal control subjects (1.16 \pm 0.04 , $p=0.006)$. To establish whether the reduced natural killer
\end{abstract}

cell number is genetically determined we studied 19 identical twin pairs discordant for Type 1 diabetes; we found that even the non-diabetic co-twins had a reduced natural killer cell number $(0.93 \pm 0.05, p=0.0006)$ as compared with normal control subjects. Natural killer cell function was similar in all groups while natural killer activity per cell was significantly increased in the recently diagnosed diabetic patients $(1.63 \pm 0.07)$ as compared with long-standing diabetic patients $(1.26 \pm 0.26, p=0.03)$ and controls subjects $(1.36 \pm 0.07$, $p=0.006$ ). In conclusion the reduced number of natural killer cells in Type 1 diabetes appears to be genetically determined while their activity at diagnosis is increased.

Key words: Natural killer cells, identical twins.
The aim of the present study was to investigate the number and cytotoxic function of natural killer (NK) cells in Type 1 (insulin-dependent) diabetes. The immune system has been implicated in the pathogenesis of Type 1 diabetes [1] since recently diagnosed Type 1 diabetic patients have islet cell antibodies $[2,3]$, increased levels of activated T-lymphocytes $[4,5]$ and mononuclear cell infiltration of their pancreatic islets [6]. These immune changes are likely to result from environmental factors, possibly viruses $[7,8]$, acting on a genetically susceptible individual.

Natural killer cells are primary effectors of antiviral defense and lyse virus-infected cells $[9,10]$. These cells can be accurately identified by monoclonal antibodies such as B73.1 and anti-Leu 11 which recognise phenotypes present on cells with NK function [11, 12]. The cytotoxic function of NK cells can be assessed by culturing NK cells with suitable target cells [13]. Previous studies which attempted to identify NK cells in Type 1 diabetes used techniques which are no longer considered valid [14]. Thus, neither anti-Leu 7 monoclonal antibody $[15,16]$ nor low affinity sheep erythrocyte ro- setting [17] correctly characterise NK cells. Anti-Leu 7 antibody recognises only a terminal stage of NK cell maturation [18] while low affinity rosetting does not specifically recognise cells with NK function [19, 20].

Therefore, we studied NK cell number, using the monoclonal antibody anti-Leu 11, and NK cell function in Type 1 diabetic patients. In order to establish whether any abnormality in NK cell number or function in diabetic patients is influenced by hyperglycaemia or genetic factors we also investigated identical twin pairs discordant for diabetes.

\section{Subjects and methods}

We studied: (1) Thirty-four Type 1 diabetic patients (18 males, $16 \mathrm{fe}-$ males, median age 38 years, range $2-78$ ); 16 had been diagnosed within one year (median 1 day, range 1 day-9 months) 11 of them were recently diagnosed and the remaining 5 were between 5-9 months after diagnosis; 18 had been diagnosed for more than 15 years (median 22 years, range 15-50); (2) Eighteen Type 2 diabetic patients ( 8 males, 10 females, median age 64 years, range 44-77); (3) Nineteen identical twin pairs discordant for Type 1 diabetes 
( 9 males, 10 females, median age 36 years, range $11-75$ ); 9 pairs were short term discordant (median discordance time 2 years, range 6 months- 3 years) and the remainder were long term discordant (median discordance time 15 years, range 15-19 years). Twins of 18 of the 19 pairs were living apart. (4) Twenty-three normal healthy control subjects (14 males, 9 females, median age 32 years, range 14-70).

\section{Preparation of lymphocytes}

Peripheral blood mononuclear cells (PBMC) were isolated from heparinised venous blood by sedimentation on a Ficoll-hypaque gradient (Pharmacia, Uppsala, Sweden) [21], washed in Hank's balanced salt solution (Gibco, Paisley, Scotland) and resuspended in RPMI 1640 medium (Gibco) containing $2 \mathrm{mmol} / 1$ glutamine, $200 \mathrm{U} / \mathrm{ml}$ penicillin, $100 \mu \mathrm{g} / \mathrm{ml}$ streptomycin and supplemented with $10 \%$ foetal calf serum.

\section{Detection of NK cells}

PBMC were stained by direct immunofluorescence with fluorescein labelled monoclonal anti-Leu 11 (Becton \& Dickinson, Monoclonal Center, Mountain View, Calif, USA) [12]. One-hundred microlitres of PBMC at $4 \times 10^{6} / \mathrm{ml}$ concentration were incubated with saturating amounts of anti-Leu 11 for $30 \mathrm{~min}$ at $4^{\circ} \mathrm{C}$. After washing, the percentage of positive cells was determined using a U.V. microscope (Polyvar Reichert-Jung Fluorescence Microscope, Vienna, Austria). At least 400 cells were counted by a single observer unaware of the clinical details. The results are expressed as the percentage of NK cells in the PBMC population.

\section{Natural killer cytotoxicity assay}

The myeloid cell line K562 grown in suspension was used as a NKsenstive target [22]. The assay used was a standard short-term $(4 \mathrm{~h})$ chromium-release assay. Briefly, $\mathrm{K} 562$ target cells were labelled by incubation in $\left.\mathrm{Na}_{2}{ }^{51} \mathrm{Cr}\right] \mathrm{O}_{4}$ for $1 \mathrm{~h}$ at $37^{\circ} \mathrm{C}$, using $100 \mu \mathrm{Ci} / 10^{7}$ cells in a volume of $0.5 \mathrm{ml}$. After washing and resuspending to $1 \times 10^{5}$ cells $\mathrm{ml}, 100 \mu \mathrm{l}$ of K562 target cells were mixed in the wells of a plastic plate (Nunc Plastic, Poskilde, Denmark) with $100 \mu \mathrm{l}$ of PBMC at varying concentrations to give effector: target cells ratios of $40: 1$, 20:1, 10:1. Quadruplicates were performed at each dilution. After incubation for $4 \mathrm{~h}$ in $5 \% \mathrm{CO}_{2}$ at $37^{\circ} \mathrm{C}, 100 \mu \mathrm{l}$ supernatants were harvested for counting in a gamma counter (LKB, 1260 MultiGamma, Bromma, Sweden). Spontaneous release of ${ }^{51} \mathrm{Cr}$ was measured in wells containing unlabelled K562 target cells as effector. Maximum release was measured by incubation of target cells in 10\% Triton- 100 .

$\% \mathrm{NK}$ activity $=$

$\frac{\text { experimental }{ }^{51} \mathrm{Cr} \text { release }- \text { spontaneous }{ }^{51} \mathrm{Cr} \text { release }}{\text { maximum }{ }^{51} \mathrm{Cr} \text { release }- \text { spontaneous }{ }^{51} \mathrm{Cr} \text { release }} \times 100$

Spontaneous release was between $7-13 \%$ of total labelled in all experiments.

Cytotoxic function was expressed as lytic units (LU) per $10^{7}$ PBMC. A LU was defined as the number of PBMC needed to effect $33 \%$ cytotoxicity. LU were calculated from the cytotoxicity curve for each test [19].

The NK cell function was related to the frequencies of NK cells by dividing the LU/ $10^{6}$ PBMC cells by the number of Leu 11 positive cells (LU/10 $/$ Leu 11) [23].

\section{Interferon effect}

A fraction of PBMC from each patient was preincubated with alpha interferon (INF) (Wellcome Diagnostics, Beckenham, England) at a concentration of $10^{3} \mathrm{IU} / \mathrm{ml}$ for $1 \mathrm{~h}$ at $37^{\circ} \mathrm{C}$. INF normally enhances the cytotoxic activity of NK cells [24]. These cells were used in the NK cytotoxicity assay. Another fraction of cells was incubated in the same way in the absence of IFN and served as control. Both the numbers of Leu 11 positive NK cells and their natural killing function were assessed from samples taken at the same time.

\section{Statistical analysis}

Results are expressed as mean $\pm \mathrm{SEM}$. All data have been $\log _{10}$-transformed because of the marked variation in the level of NK cell number and function among individuals and to stabilise the variation around the $\log _{10}$-transformed mean. Following $\log _{10}$ transformation the results corresponded to a normal distribution in that $66 \%$ of them were within 1SD of the mean. For comparison of NK cell number, function, and function per single cell among groups, the geometric means of each group were compared by subjecting the $\log _{10}$-transformed values of individual observations to two-tailed Student's t-test. To asses whether observations were correlated, we used the correlation coefficient $r$.

\section{Results}

\section{NK cell number}

Of the peripheral blood mononuclear cells the mean ( $\log _{10}$-transformed) percentage of NK cells was significantly lower in Type 1 diabetic patients $(1.01 \pm 0.04)$ than in Type 2 diabetic patients $(1.16 \pm 0.04, p=0.004)$ and normal control subjects $(1.16 \pm 0.04, p=0.006)$ (Fig.1). The mean levels were similar in recently diagnosed $(0.97 \pm 0.05)$ and long-standing diabetic patients $(1.05 \pm 0.04, p=0.13)$. Of the six recently diagnosed diabetic patients tested repeatedly, four had levels less than the normal range (less than 0.89) which remained low on all 11 occasions they were tested, while two had

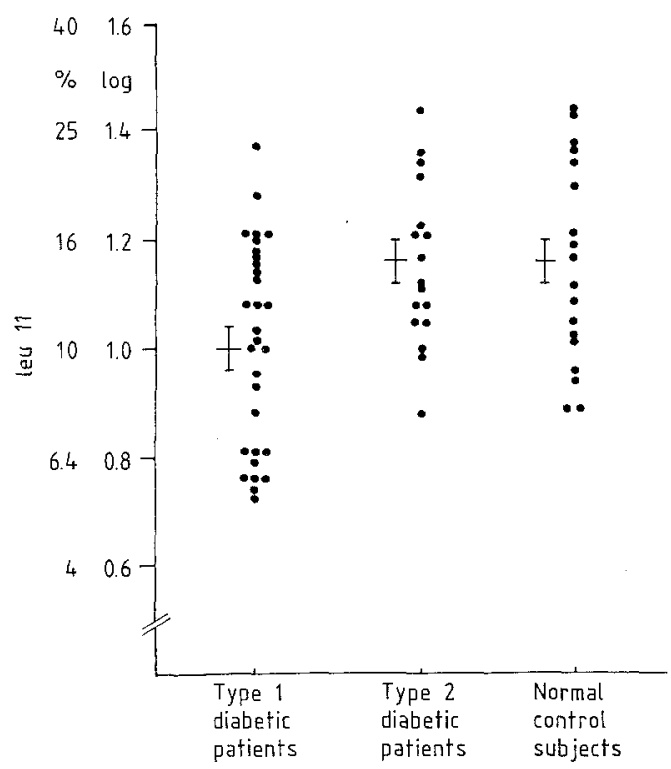

Fig. 1. Number of natural killer cells expressed as percentage and $\log _{10}$. transformed values in Type 1 diabetic patients, Type 2 diabetic patients and normal control subjects. Horizontal bars represent mean \pm SEM percent of the natural killer cell number. This is significantly lower in Type 1 patients when compared to Type 2 patients $(p=0.004)$ and normal control subjects $(p=0.006)$ 


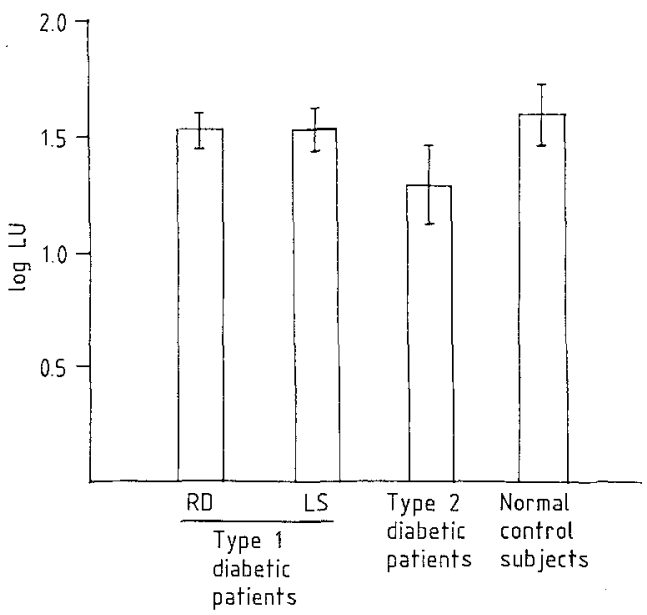

Fig. 2. Mean $\pm \mathrm{SEM}$ natural killer cell function expressed as $\log _{10}$. transformed lytic units (LU) in patients with recently diagnosed (RD) Type 1 diabetes, long-standing (LS) Type 1 diabetes, Type 2 diabetes and normal control subjects

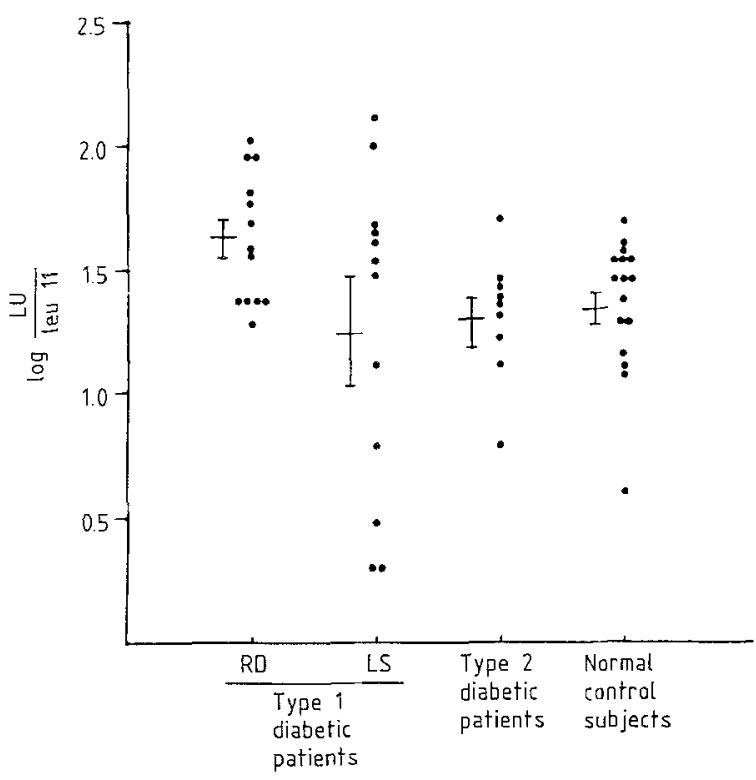

Fig. 3. Natural killer cell function per single cell expressed as a ratio between lytic units (LU) and the number of Leu 11 positive cells ( $\log _{10}$ transformed) in patients with recently diagnosed (RD) Type 1 diabetes, long-standing (LS) Type 1 diabetes, Type 2 diabetes and normal control subjects. Horizontal bars represent mean \pm SEM natural killer cell function per single cell. This is significantly higher in recently diagnosed Type 1 patients than long-standing Type 1 patients $(p=0.03)$, Type 2 patients $(p=0.005)$ and normal control subjects $(p=0.006)$

normal levels which remained normal on all six occasions they were tested. The percentage of NK cell number did not correlate with the age of the patients $(r=0.15)$.

\section{$N K$ cell function}

Mean NK cell function of peripheral blood mononuclear cells (expressed as the $\log _{10}$-transformed lytic units per $10^{7}$ peripheral blood mononuclear cells) was not significantly different in recently diagnosed $(1.54 \pm$ $0.07, p=0.4)$, long-standing Type 1 diabetic patients $(1.54 \pm 0.09, p=0.4)$ and Type 2 diabetic patients $(1.29 \pm 0.16, p=0.08)$ when compared to each other or normal control subjects $(1.60 \pm 0.13)$ (Fig. 2). The percentage change in NK cell function after alpha-interferon did not differ significantly from control subjects $(20 \%)$ in recently diagnosed Type 1 diabetic patients $(22 \%, p=0.45)$, long-standing Type 1 diabetic patients $(26 \%, p=0.23)$ and Type 2 diabetic patients $(28 \%$, $p=0.13)$.

\section{NK function per cell}

Mean NK function per single Leu 11 positive cell ( $\log _{10}$-transformed) was significantly higher in recently diagnosed Type 1 diabetic patients $(1.63 \pm 0.07)$ than in long-standing Type 1 diabetic patients $(1.26 \pm 0.26$, $p=0.03)$, Type 2 diabetic patients $(1.31 \pm 0.09$, $p=0.005)$ and normal control subjects $(1.36 \pm 0.07$, $p=0.006$ ) (Fig. 3). Of the five recently diagnosed Type 1 diabetic patients tested repeatedly, one had levels above the normal range (greater than 1.7) on both occasions while the remainder had normal levels on 11 out of 12 occasions (one had a high level in one of four tests).

\section{NK cell number and function}

NK cell number and function of Leu 11 positive cells were significantly correlated in normal control subjects $(r=0.69, p=0.01)$ but in neither Type 1 diabetic patients $(r=0.28)$ nor in Type 2 diabetic patients $(r=0.02)$.

\section{Identical twin pairs}

\section{NK cell number}

In the 19 identical twin pairs the percentage of NK cells was significantly reduced in both diabetic $(0.91 \pm 0.05, \quad p=0.0005)$ and non-diabetic twins $(0.93 \pm 0.05, p=0.0006)$ when compared with normal control subjects $(1.16 \pm 0.04)$. The number of NK cells was correlated in the diabetic twin and non-diabetic co-twins ( $r=0.66, p=0.004$ ) (Fig. 4).

\section{NK cell function}

NK cell function did not differ in the diabetic $(1.49 \pm$ $0.09, p=0.24)$ and non-diabetic $(1.43 \pm 0.11, p=0.13)$ twins from normal control subjects $(1.60 \pm 0.13)$. There was no significant correlation of NK function between the diabetic patients and their non-diabetic co-twins $(r=0.06, p=0.84)$. 


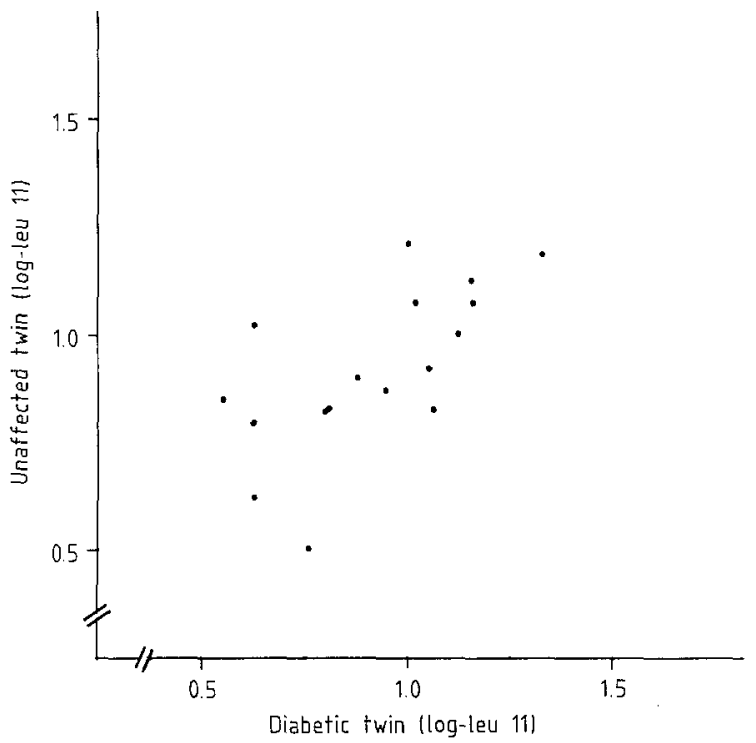

Fig.4. Correlation for the number of natural killer cells, expressed as $\log _{10}$-transformed percentage of Leu 11 positive cells, between diabetic twin and non-diabetic co-twin $(r=0.66, p=0.004)$. The $95 \%$ confidence interval for the correlation coefficient is $0.26-0.87$

\section{NK function per cell}

NK cell function per single cell did not differ in the diabetic $(1.41 \pm 0.11, \quad p=0.32)$ and non-diabetic $(1.49 \pm 0.1, p=0.13)$ twins when compared with normal control subjects $(1.36 \pm 0.07)$. The NK cell function per single cell in the diabetic twins correlated with that in their non-diabetic co-twins ( $r=0.65, p=0.01$ ).

None of the diabetic twins was tested within 1 year of their diagnosis so we have no group of recently diagnosed diabetic twins to compare with the recently diagnosed diabetic singletons.

\section{Discussion}

This study demonstrates that Type 1 diabetic patients tend to have reduced numbers of natural killer cells. This reduction cannot be due solely to hyperglycaemia, since no change is found in Type 2 diabetic patients. We believe that the reduction in NK cell number is genetically determined because reduced numbers of these cells are found in both diabetic and non-diabetic identical twins, and, in them, the levels correlate significantly. In addition, the decrease in NK cells occurred irrespective of the duration of the disease.

In contrast to NK cell number, the overall NK cell function and response to interferon is normal in both groups of diabetic patients. It is likely that only large disturbances in NK cell function could be detected with the assay used in this study. These results are in apparent contrast to a recent report of decreased NK cell function in Type 1 diabetic patients [16]. However, in that study the population of cells used to asses NK function was depleted of T-lymphocytes which sub- stantially contribute to NK function [19]. In our present study all cells with NK function were investigated. One might anticipate an increase in the NK cell function per single cell in Type 1 diabetes, since, in spite of the reduction in the NK cell number, the NK cell function was normal. However, we found that only the recently diagnosed Type 1 diabetic patients had an increase in NK cell function per single cell.

We do not know why an NK cell has increased function at, or soon after the diagnosis of Type 1 diabetes. Enhanced NK cell function can occur following viral infection or exposure to soluble factors released by activated T-lymphocytes [25, 26]. Recently diagnosed Type 1 diabetic patients show increased levels of activated T-lymphocytes $[4,5]$. Thus, enhanced NK cell function in recently diagnosed Type 1 diabetes might be due either to a response to soluble factors released from activated $\mathrm{T}$-lymphocytes or a factor which itself causes activation of T-lymphocytes.

In conclusion NK cell numbers tend to be reduced in Type 1 diabetes and this feature may be genetically determined. On the other hand, the NK function of each cell is increased in recently diagnosed Type 1 diabetes when there is also activation of T-lymphocytes.

Acknowledgements. MJH is in receipt of a grant from the Joint Research Committee-King's College Hospital. LA is supported by the Cowburn fellowship. BAM is an MRC research fellow. RDGL is a Wellcome Trust senior fellow. This study was partly funded by the British Diabetic Association.

\section{References}

1. Cahill GF, McDevitt HO (1984) Insulin-dependent diabetes mellitus: the initial lesion. N Engl J Med 304: 1454-1465

2. Bottazzo GF, Florin-Christensen A, Doniach D (1974) Islet-cell antibodies in diabetes mellitus with autoimmune polyendocrine deficiencies. Lancet II: 1279-1282

3. Bottazzo GF, Dean BM, Gorsuch AN, Cudworth AG, Doniach $\mathrm{D}$ (1980) Complement-fixing islet-cell antibodies in type I diabetes: possible monitors of active beta-cell damage. Lancet I: 668-672

4. Jackson RH, Morris MA, Haynes BF, Eisenbarth G (1982) Increased circulating Ia-antigen bearing T-cells in type I diabetes mellitus. N Engl J Med 305: 785-788

5. Alviggi L, Johnston C, Hoskins PJ, Tee DEH, Pyke DA, Leslie RDG, Vergani D (1984) Pathogenesis of insulin-dependent diabetes: a role for activated T lymphocytes. Lancet II: 4-6

6. Gepts W (1965) Pathological anatomy of the pancreas in juvenile diabetes mellitus. Diabetes 14: 619-633

7. Toniolo A, Onodera T (1984) Viruses and diabetes. In: Andreani D, Di Mario U, Federlin KF, Heding LG (eds) Immunology in Diabetes. Kimpton Medical publications, London, pp 71-92

8. Bottazzo GF, Pujol-Borrell R, Gale E (1985) Etiology of diabetes: the role of autoimmune mechanisms. In: Alberti KGMM, Krall LP (eds) The Diabetes Annual Vol 1. Elsevier Science Publishers BV, Amsterdam, pp 16-52

9. Welsh MR (1981) Natural cell-mediated immunity during viral infections. Curr Top Microbiol 92: 83-106

10. Herberman RB, Ortaldo JR (1981) Natural killer cells: their role in defenses against disease. Science 214: 24-30

11. Perussia B, Starr S, Abraham S, Fanning V, Trinchieri G (1983) Human natural killer cells analysed by B 73.1, a monoclonal anti- 
body blocking Fc receptor functions. I. characterization of the lymphocyte subset reactive with B73.1. J Immunol 130: $2133-2141$

12. Phillips JH, Babcock GF (1983) NKP-15: a monoclonal antibody reactive against purified natural killer cells and granulocytes. Immunol Lett 6: 143-149

13. West WH, Cannon GB, Kay HD, Bonnard GD, Herbermann RB (1977) Natural cytotoxic reactivity of human lymphocytes against a myeloid cell line: characterisation of effector cells. J Immunol 118: 355-361

14. Lanier LL, Phills JH, Warner NL, Babcock GF (1984) A human NK cell associated antigen defined by monoclonal antibody antiLeu 11a (NKP-15): functional and two-color flow cytometry analysis. J Leukocyte Biol 35: 11-17

15. Chandy KG, Charles MA, Buckingham B, Waldeck N, Kershnar A, Gupta S (1984) Deficiency of monoclonal antibody (Leu 7) defined NK cells in newly diagnosed insulin-dependent diabetes mellitus. Immunol Lett 8:89-91

16. Negishi K, Waldeck $N$, Chandy G, Buckingham B, Kershnar A, Fisher L, Gupta S, Charles MA (1986) Natural killer cell and islet killer cell activity in Type 1 (insulin-dependent) diabetes. Diabetologia 29: 352-357

17. Pozzilli P, Sensi M, Gorsuch A, Bottazzo GF, Cudworth AG (1979) Evidence for raised K-cell levels in type I diabetes. Lancet II: $173-175$

18. Phillips JH, Lanier LL (1985) A model for the differentiation of human natural killer cells. Studies on the in vitro activation of Leu-11 + granular lymphocytes with natural killer-sensitive tumor cell, K 562. J Exp Med 161: 1464-1482

19. Trinchieri G, Perussia B (1984) Human natural killer cells: biologic and pathologic aspects. Lab Invest 50: 489-513
20. West WH, Cannon GB, Kay HD, Bonnard GD, Herberman RB (1977) Natural cytotoxic reactivity of human lymphocytes against a myeloid cell line: characterization of effector cells. J Immunol 118: $355-361$

21. Böyun A (1968) Separation of leukocytes from blood and bonemarrow. Introduction. Scand J Clin Lab Invest 21 [Suppl] 97: 7

22. Pross HF, Baines MG, Rubin P, Shragge P, Patterson MS (1981) Spontaneous human lymphocyte-mediated cytotoxicity against tumour target cells. IX. The quantitation of natural killer cell activity. J Clin Immunol 1: 51-63

23. Timonen T, Stenins-Aarninla B (1985) Natural killer activity in asthma. Clin Exp Immunol 59: 85-90

24. Perussia B, Santoli D, Trinchieri G (1980) Interferon modulation of natural killer cell activity. Ann NY Acad Sci 350: 55-62

25. Herbermann RB, Nunn ME, Holden HT, Staal S, Djen JY (1977) Augmentation of natural cytotoxic reactivity of mouse lymphoid cells against syngeneic and allogeneic target cells. Int J Cancer 19:555-564

26. Koide Y, Takasugi M (1978) Augmentation of human natural cell-mediated cytotoxicity by a soluble factor. I. Production of $\mathrm{N}$-cell-activating factor (NAF). J Immunol 121: 872-879

Received: 23 January 1987

and in revised form: 22 October 1987

Dr. D. Vergani

Department of Immunology

King's College School of Medicine and Dentistry

Denmark Hill

London SE 58 RX

UK 